PLOS ONE

\title{
Seed encrusting with salicylic acid: a novel approach to improve establishment of grass species in ecological restoration --Manuscript Draft--
}

\begin{tabular}{|c|c|}
\hline Manuscript Number: & PONE-D-20-33303 \\
\hline Article Type: & Research Article \\
\hline Full Title: & $\begin{array}{l}\text { Seed encrusting with salicylic acid: a novel approach to improve establishment of } \\
\text { grass species in ecological restoration }\end{array}$ \\
\hline Short Title: & $\begin{array}{l}\text { Seed encrusting with salicylic acid to improve establishment of grass species in } \\
\text { ecological restoration }\end{array}$ \\
\hline Corresponding Author: & $\begin{array}{l}\text { Simone Pedrini } \\
\text { Curtin University } \\
\text { Bentley, WA AUSTRALIA }\end{array}$ \\
\hline Keywords: & $\begin{array}{l}\text { seed coating; seed enhancement; germination; emergence; grassland; } \\
\text { demographic process }\end{array}$ \\
\hline Abstract: & $\begin{array}{l}\text { To achieve global ambitions in large scale ecological restoration, there is a need for } \\
\text { approaches that improve the efficiency of seed-based restoration, particularly in } \\
\text { overcoming the bottleneck in the transition from germination to seedling establishment. } \\
\text { In this study we tested a novel seed-based application of the plant stress modulator } \\
\text { compound, salicylic acid, as a means to reduce seedling losses in seed-to-seedling } \\
\text { phase. First-time seed coating technology (encrusting) was developed as a precursor } \\
\text { for optimising field sowing for three grass species commonly used in restoration } \\
\text { programs, Austrostipa scabra, Microlaena stipoides, and Rytidosperma geniculata } \\
\text {. Salicylic acid (SA, 0.1mM) was delivered to seeds via imbibition and seed encrusting } \\
\text { with the effects tested on seed germination under controlled conditions (to test for } \\
\text { resilience to drought), and in field conditions on seedling emergence, plant survival, } \\
\text { and seedling growth. SA did not significantly impact germination under water stress in } \\
\text { controlled laboratory condition and did not affect seedling emergence in the field. } \\
\text { However, seedling survival and growth was improved in plants from SA treated seeds } \\
\text { (imbibed and encrusted) under field conditions. When SA delivery mechanisms of } \\
\text { imbibing and coating were compared, there was no significant difference in survival } \\
\text { and growth, showing that seed coating has potential to deliver SA. Effect of } \\
\text { intraspecific competition as a result of seedling density was also considered. Seedling } \\
\text { survival over the dry summer season more than doubled when seed was sown at low } \\
\text { density ( } 40 \text { plants/m } 2 \text { ) compared to high density seeding (380 plants/m } 2 \text { ). Overall, } \\
\text { adjustment of seeding rate according to expected emergence combined with the use of } \\
\text { salicylic acid is a cost-effective means for improving seed use efficiency in seed-based } \\
\text { restoration. }\end{array}$ \\
\hline \multirow[t]{4}{*}{ Order of Authors: } & Simone Pedrini \\
\hline & Jason C. Stevens \\
\hline & Adam T. Cross \\
\hline & Kingsley W. Dixon \\
\hline \multicolumn{2}{|l|}{ Additional Information: } \\
\hline Question & Response \\
\hline Financial Disclosure & $\begin{array}{l}\text { SP and AC were supported by the Australian Research Council Industrial } \\
\text { Transformation }\end{array}$ \\
\hline $\begin{array}{l}\text { Enter a financial disclosure statement that } \\
\text { describes the sources of funding for the } \\
\text { work included in this submission. Review } \\
\text { the submission guidelines for detailed } \\
\text { requirements. View published research } \\
\text { articles from PLOS ONE for specific }\end{array}$ & $\begin{array}{l}\text { Training Centre for Mine Site Restoration (Project Number ICI150100041). The funder } \\
\text { did not play any role in the study design, data collection and analysis, decision to } \\
\text { publish, or preparation of the manuscript? }\end{array}$ \\
\hline
\end{tabular}


examples.

This statement is required for submission and will appear in the published article if the submission is accepted. Please make sure it is accurate.

\section{Unfunded studies}

Enter: The author(s) received no specific funding for this work.

\section{Funded studies}

Enter a statement with the following details:

- Initials of the authors who received each award

- Grant numbers awarded to each author

- The full name of each funder

- URL of each funder website

- Did the sponsors or funders play any role in the study design, data collection and analysis, decision to publish, or preparation of the manuscript?

- NO - Include this sentence at the end of your statement: The funders had no role in study design, data collection and analysis, decision to publish, or preparation of the manuscript.

- YES - Specify the role(s) played.

* typeset

\section{Competing Interests}

The authors have declared that no competing interests exist.

Use the instructions below to enter a competing interest statement for this submission. On behalf of all authors, disclose any competing interests that could be perceived to bias this work-acknowledging all financial support and any other relevant financial or nonfinancial competing interests.

This statement will appear in the published article if the submission is accepted. Please make sure it is accurate. View published research articles from PLOS ONE for specific examples. 


\section{NO authors have competing interests \\ Enter: The authors have declared that no competing interests exist. \\ Authors with competing interests \\ Enter competing interest details beginning with this statement: \\ I have read the journal's policy and the authors of this manuscript have the following competing interests: [insert competing interests here] \\ * typeset}

\section{Ethics Statement}

Enter an ethics statement for this submission. This statement is required if the study involved:

- Human participants

- Human specimens or tissue

- Vertebrate animals or cephalopods

- Vertebrate embryos or tissues

- Field research

Write "N/A" if the submission does not require an ethics statement.

General guidance is provided below.

Consult the submission guidelines for detailed instructions. Make sure that all information entered here is included in the Methods section of the manuscript. 


\section{Format for specific study types}

Human Subject Research (involving human participants and/or tissue)

- Give the name of the institutional review board or ethics committee that approved the study

- Include the approval number and/or a statement indicating approval of this research

- Indicate the form of consent obtained (written/oral) or the reason that consent was not obtained (e.g. the data were analyzed anonymously)

\section{Animal Research (involving vertebrate}

\section{animals, embryos or tissues)}

- Provide the name of the Institutional Animal Care and Use Committee (IACUC) or other relevant ethics board that reviewed the study protocol, and indicate whether they approved this research or granted a formal waiver of ethical approval

- Include an approval number if one was obtained

- If the study involved non-human primates, add additional details about animal welfare and steps taken to ameliorate suffering

- If anesthesia, euthanasia, or any kind of animal sacrifice is part of the study, include briefly which substances and/or methods were applied

\section{Field Research}

Include the following details if this study involves the collection of plant, animal, or other materials from a natural setting:

- Field permit number

- Name of the institution or relevant body that granted permission

\section{Data Availability}

Yes - all data are fully available without restriction

Authors are required to make all data underlying the findings described fully available, without restriction, and from the time of publication. PLOS allows rare exceptions to address legal and ethical concerns. See the PLOS Data Policy and FAQ for detailed information. 
A Data Availability Statement describing where the data can be found is required at submission. Your answers to this question constitute the Data Availability Statement and will be published in the article, if accepted.

Important: Stating 'data available on request from the author' is not sufficient. If your data are only available upon request, select 'No' for the first question and explain your exceptional situation in the text box.

Do the authors confirm that all data underlying the findings described in their manuscript are fully available without restriction?

Describe where the data may be found in All relevant data are within the manuscript and its Supporting Information files. full sentences. If you are copying our sample text, replace any instances of $X X X$ with the appropriate details.

- If the data are held or will be held in a public repository, include URLs, accession numbers or DOls. If this information will only be available after acceptance, indicate this by ticking the box below. For example: $A$ II $X X X$ files are available from the $X X X$ database (accession number(s) $X X X, X X X$.).

- If the data are all contained within the manuscript and/or Supporting Information files, enter the following: All relevant data are within the manuscript and its Supporting Information files.

- If neither of these applies but you are able to provide details of access elsewhere, with or without limitations, please do so. For example:

Data cannot be shared publicly because of $[X X X]$. Data are available from the $X X X$ Institutional Data Access / Ethics Committee (contact via $X X X)$ for researchers who meet the criteria for access to confidential data.

The data underlying the results presented in the study are available from (include the name of the third party 
and contact information or URL).

- This text is appropriate if the data are owned by a third party and authors do not have permission to share the data.

* typeset

Additional data availability information: 


\section{Seed encrusting with salicylic acid: a novel approach to \\ 2 improve establishment of grass species in ecological \\ 3 restoration \\ 4}

5 Simone Pedrini ${ }^{1 *}$, Jason C. Stevens ${ }^{2,3}$, Adam Cross $^{4,5}$ and Kingsley W. Dixon ${ }^{1,3}$

6

$7 \quad{ }^{1}$ ARC Centre for Mine Site Restoration, School of molecular and life science, Curtin University, Kent Street,

8 Bentley, 6102, Western Australia

92 Kings Park Science, Department of Biodiversity, Conservation and Attractions, 2 Kattidj Close, Kings Park, 6005, Western Australia

${ }^{3}$ School of Biological Sciences, The University of Western Australia, 35 Stirling Highway, Crawley WA 6009,

Western Australia.

${ }^{4}$ EcoHealth Network, 1330 Beacon St, Suite 355a, Brookline, MA 02446, United States.

${ }^{5}$ School of Molecular and Life Sciences, Curtin University, Kent Street, Bentley, WA 6102, Australia.

*Corresponding author: simone.pedrini@curtin.edu.au process 


\section{Abstract}

25 To achieve global ambitions in large scale ecological restoration, there is a need for approaches that improve the efficiency of seed-based restoration, particularly in overcoming the bottleneck in the transition from germination to seedling establishment. In this study we tested a novel seed-based application of the plant stress modulator compound, salicylic acid, as a means to reduce seedling losses in seed-to-seedling phase. First-time seed coating technology (encrusting) was developed as a precursor for optimising field sowing for three grass species commonly used in restoration programs, Austrostipa scabra, Microlaena stipoides, and Rytidosperma geniculata. Salicylic acid (SA, $0.1 \mathrm{mM}$ ) was delivered to seeds via imbibition and seed encrusting with the effects tested on seed germination under controlled conditions (to test for resilience to drought), and in field conditions on seedling emergence, plant survival, and seedling growth. SA did not significantly impact germination under water stress in controlled laboratory condition and did not affect seedling emergence in the field. However, seedling survival and growth was improved in plants trom SA treated seeds (imbibed and encrusted) under field conditions. When SA delivery mechanisms of imbibing and coating were compared, there was no significant difference in survival and growth, showing that seed coating has potential to deliver SA. Effect of intraspecific competition as a result of seedling density was also considered. Seedling survival over the dry summer season more than doubled when seed was sown at low density $\left(40\right.$ plants $/ \mathrm{m}^{2}$ ) compared to high density seeding ( 380 plants $\left./ \mathrm{m}^{2}\right)$. Overall, adjustment of seeding rate according to expected emergence combined with the use of salicylic acid is a costeffective means for improving seed use efficiency in seed-based restoration. 


\section{Introduction}

Almost two-thirds of the world ecosystems are considered degraded or damaged with a lack of restorative effectiveness often unable to compensate for ecosystem loss [1]. Such degradation poses a serious risk to biodiversity, and impacts human communities that rely on ecosystem services for their sustenance and wellbeing $[2,3]$. Once degradation has occurred, restorative activities can be used to return the functionality, diversity, and structure of healthy, intact, and sustainable ecosystems $[4,5]$. Grasslands are among the most extensive terrestrial ecosystems in the world, covering over 52.5 million $\mathrm{km}^{2}$ [6], and provide fundamental ecosystem services such as sustaining food production (e.g., through rangeland pastoralism and dairy), carbon sequestration and storage, and erosion control [7]. However, almost half of the global grassland estate is considered degraded

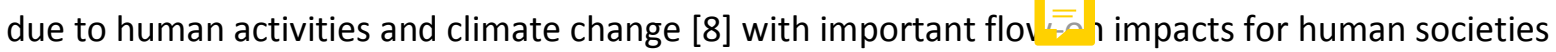
whose livelihoods depend upon these grasslands.

In cases li... Jf extreme disturbance, like post mining lands $\cdot \overline{\overline{a n}}$ e, where spontaneous regeneration may not be feasible or effective, restorative interventions are required [9]. Native seeds of appropriate-local origin are commonly used to reintroduce missing species and to perform ecological restoration when the land has limited natural regenerative capacity $[10,11]$. However, abiotic factors such as nutrient-impoverishment, chemical and physically-hostile soil conditions [12] and low or unpredictable water availability [13], combined with biotic variables such as seed predation [14] and competition with exotic species, cumbine to limit the success of traditional seed-based grassland restoration.

Generally, less than $10 \%$ of sown native seeds become established plants, with significant bottlenecks detected at the seedling emergence phase [15], and in survival through the first summer drought [16]. Given the high cost and often highly limited availability of native seed [17], improving the efficiency in deployment to site is crucial if ecological restoration is to be delivered at the landscape scales expected [18] such as the UN Decaae of Ecosystem Restoration. To address issues 
related to logistical constraints on seed delivery, and seedling establishment, the crop seed industry has developed technologies, such as seed coating, that could be adapted and applied to native seed [19].

Seed coating is the practice of covering seeds with external materials, sometimes including active ingredients conferring seeds protection and improved physiological performance [20]. Seed coating has been tested on native seeds in different restoration scenarios to overcome specific limitations such as water repellency [21], soil crusting [22], and seed predation [23]. However, despite promising results in seed coating improving seedling emergence, limited studies have so far attempted to improve native seed germination and seedling resistance to abiotic stresses [24].

Resistance to some abiotic stresses could be conferred by exposure of seeds to salicylic acid (SA). SA is a plant hormone, synthesised by many plant species [25]. It is involved in plant growth, developmental regulation [26], signalling [27], thermogenesis and mediating stress response either by providing resistance or triggering apoptosis [28]. Exogenous application of SA through watering, foliar spray, or seed imbibition has shown increased plant resistance and survival to a wide range of abiotic and biotic stresses [29]. SA efficacy in conferring stress resistance is a function of its concentration, with low concerı ations failing to deliver resistance and higher concentrations decreasing resistance by activating cell death pathways [30,31]. The effect of SA on seed germination remains unclear; studies using seeds of crop species report improved germination for Arabidopsis thaliana under salinity stress [32] and for wheat (Triticum aestivum) under drought stress [33], while no effect was reported for maize (Zea mays) [34] or barley (Hordeum vulgare) [35]. Seed coating delivery of SA has shown some promising results when tested on tobacco seeds, improving germination and seedling growth under drought stress [36], and on corn, inducing resistance to chilling [37]. However, it has never been tested on native species for ecological restoration. 
The goal of this study is to evaluate the effects of SA applied to seed on germination success, seedling emergence, survival and growth on three grass species native to southern temperate Australia, and to compare SA delivery methods via imbibition and coating.

The following hypotheses were tested: 1) coating or imtinicion of seeds, without inclusion of SA, will not deleteriously impact seed germination success in laboratory trials or seedling emergence in the field, 2) SA will improve germination under conditions of water stress and enhance seed germination and seedling emergence in the field, and 3) plant survival and growth in the field will be improved for plants established from SA treated seeds at low and high intraspecific com.

\section{Material and methods}

\section{Species selection and seed processing}

Three species of grasses native to temperate and Mediterranean regions of southern Australia were selected on the basis of their predominance in grassland revegetation and restoration activities and utility as pasture [38], including Austrostipa scabra (Lindl.) S.W $\bar{\mp}$ Jacobs \& J.Everett, Microlaena stipoides (Labill.) R.Br. var. Griffin and Rytidosperma geniculata (J.M.Black) Connor \& Edgar var. Oxley (all Poaceae). Seeds were sourced from a commercial provider (Native Seed Pty Ltd, Cheltenham, Victoria) in 2016. To reduce potential for viability loss seeds were stored in paper bags on open shelving in a controlled environment $\left(15^{\circ} \mathrm{C}\right.$, and $15 \%$ relative humidity, $\left.\mathrm{RH}\right)$ for one year prior to experimentation [39]. Seeds were moved to ambient condition $\left(20-25^{\circ} \mathrm{C}\right.$ and $\left.40-50 \% \mathrm{RH}\right)$ two weeks prior to experimentation to avoid potential seed damage during the cleaning and encrusting process [40].

Caryopses of each species were extracted from the husk to allow for more homogeneous encrusting and imbibition treatment. Removal of the palea and lemma was performed for each species using sulphuric acid digestion sensu Stevens et al 2015 [41], with complete immersion of the caryopsis in a $50 \%$ sulphuric acid solution (ACS reagent grade $\mathrm{H}_{2} \mathrm{SO}_{4}$, Sigma-Aldrich, St Louis, USA) for an optimal 
interval allowing for the weakening of floret structures without reducing germination potential. Immersion time for all three species was determined by Pedrini et al 2018 [42], and thus immersion intervals were $90 \mathrm{~min}$ for $A$. scabra, $60 \mathrm{~min}$ for $M$. stipoides and $20 \mathrm{~min}$ for $R$. geniculata. Acid immersion was followed by a neutralisation treatment in a $8.4 \mathrm{~g} \mathrm{~L}^{-1}$ sodium bicarbonate $\left(\mathrm{NaHCO}_{3}\right.$, Sigma-Aldrich, St Louis, USA) solution for 5 minutes, before rinsing under tap water for two minutes and drying in a Food Lab ${ }^{\mathrm{TM}}$ Electronic Dehydrator at $35^{\circ} \mathrm{C}$ (Sunbeam, Sydney, Australia). After drying, caryopsis extraction was achieved by gentle rubbing with a rubber mat and sequential sieving and zig-zag air flow separator (Selecta Machinefabriek BV, Enkhuizen, Netherlands).

\section{Seed treatments}

After cleaning, caryopses (hereafter referred to as 'seeds') of each species were subjected to seed imbibition or coating treatments with or without salicylic acid application $\left(F_{1} / \mathrm{I}\right)$, resulting in four treatments (imbibed seeds without SA, imbibed seeds with SA, coated seeds without SA, coated with SA) plus an untreated control (uncoated, unimbibed seeds without SA). The coating treatment used in this experiment is defined encrusting, because the size and weight of the seed were increased but the shape of the seed remained evident [24].

SA was provided at a concentration of $0.1 \mathrm{mM}$, a concentration previously shown to be sufficient in confering stress resistance across various species and delivery methods $[31,43,44]$. SA solution was prepared by dissolving crystalline SA (Sigma Aldrich, St. Louis, USA) in deionized water for imbibition, and in a $2 \%$ Hydroxyethyl cellulose hydroxyethyl cellulose (cellosize QP 09-L, DOW chemicals) solution for encrusting (mixed with a magnetic stirrer for 30 minutes at $50^{\circ} \mathrm{C}$ ). For imbibition treatments seeds were soaked in either SA solution or deionized water for $24 \mathrm{~h}$ at $20^{\circ} \mathrm{C}$. sensu Pedrini et al. (2018). Liquids were delivered through a compressed air-propelled $0.7 \mathrm{~mm}$ airbrush (Ozito tools, Australia). Talc was used as the filler material, dusted onto the seeds with a paint brush. Cleaned seeds $(10 \mathrm{~g})$ were placed inside the rotary coater, with rotor speed set at 300 
RPM, and seeds were initially exposed to liquid spray until moist before powder was dusted onto the rotating seed mass. Wetting and dusting were repeated until $20 \mathrm{~g}$ of powder were used. A total of 15 $\mathrm{ml}$ of liquid were applied. Seeds were routinely checked to visually evaluate the even coverage of the coat, and to assess the formation of multiple seeds or dead balls (agglomerate of coating material not containing a seed). Following imbibition and encrusting treatments, seeds were placed on trays and dried for 3 hours in a in a Food Lab ${ }^{T M}$ Electronic Dehydrator at $35^{\circ} \mathrm{C}$ (Sunbeam, Sydney, Australia).

\section{Laboratory test}

Germination tests were performed in Petri dishes lined with two filter papers moistened with $14 \mathrm{ml}$ water or Polyethylene Glycol (PEG) solution, placed in sealed plastic bags to reduce desiccation. $2 \mathrm{ml}$ of water or PEG solution was added weekly.

In order to test whether SA improved germination success under water-limited conditions PEG 8000 (Sigma-Aldrich, St Louis, USA) diluted in deionised water at $24.72,30.78$, and $35.90 \mathrm{~g} / \mathrm{l}$ was used to obtain solutions of $-0.6,-0.9$, and $-1.2 \mathrm{MPa}$ water potential at $20^{\circ} \mathrm{C}$. This value resembles the range of water availability recorded in the field during the winter months. Germination tests were performed on four replicates of 25 seeds for each of the five seed treatments. Petri dishes were placed in a Biosyn incubator $6000 \mathrm{OP}$ (Contherm, Korokoro, New Zealand) at $20^{\circ} \mathrm{C}$ with a $12 \mathrm{~h}$ photoperiod.

Germination was scored daily for the first five days and then at 7, 10 and 15 days respectively. On the 21st day, final germination was scored and remaining seed examined via cut test to assess viability. Non-viable seeds were excluded from the total.

\section{Field trials}


species and offers climatic conditions similar to those of mining operations active in the area likely to require these species in seed-based rehabilitation following mine closure. The field trial area was enclosed by a fence to avoid grazing from native marsupials and rabbits. Three experiments were performed in the field site: 1) seed germination in recoverable porous bags, 2) seedling emergence and survival in precision planted lines, and 3) plant survival and growth in plots. The five treatments previously described were tested in each experiment. For germination experiments in bags and lines, each treatment had four replicates. All experiments were arranged on a randomised complete block design of four blocks for 15 treatments ( 5 treatments $* 3$ species). For inline arı plot experiments, seed were sown at depths of $0.2-0.5 \mathrm{~cm}$, achieved by broadcasting dry soil on top of freshly sown lines and plots. All experiments were established at the commencement of the wet season in May 2017.

\section{Germination bags experiment}

Field seed germination was tested by placing 50 seeds in $5 \mathrm{~cm}^{2}$ sealed mesh bags, over a $2 \mathrm{~m}^{2}$ area, and buried on site at $1 \mathrm{~cm}$ depth. The bags were collected three weeks after sowing and germination recorded for those seeds as indicated by a protruding radicle.

\section{Line experiment - high competition}

Seedling emergence was tested by sowing 100 seeds along a meter-long line, $5 \mathrm{~cm}$ wide. Seedling emergence was scored after 1, 2, 3, 4 6, 8 and 10 weeks. All emerged seedlings were left to then grow to maturity and resulted in high intraspecitic competition. Plant survival was recorded 45 weeks after sowing.

\section{Plot experiment - low competition}

To evaluate plant survival and growth under low int. broadcasted on a $0.5 \times 0.5 \mathrm{~m}^{2}$ plot. A month after sowing, the plots were thinned to 10 seedlings randomly selected, with at least $5 \mathrm{~cm}$ between seedlings, to limit potential competition resulting in a 
density of $40 \mathrm{plant} / \mathrm{m}^{2}$. The selected seedlings were marked with a pin to avoid confusion with other seedlings that could have emerged at a later stage. 45 weeks after sowing the surviving plants were counted, harvested and their height, wet weight and dry weight recorded.

Soil temperature and volumetric moisture content $\left(\mathrm{m}^{3} / \mathrm{m}^{3}\right)$ were recorded for the duration of the germination and emergence experiment (10 weeks) with HOBO Micro Station Data Loggers (Onset Computer Corporation, Bourne, MA, USA). The probes were buried at $1 \mathrm{~cm}$. For the 35 weeks following the end of the emergence experiment (July 2017 - March 2018), minimum and maximum temperature and precipitation data were obtained from the Dwe IIIIgup weather station, $10 \mathrm{~km}$ from the site [45] (Fig 2).

\section{Statistical analysis}

To assess laboratory germination and seedling emergence in the field, non-linear regression models were fitted with the function "drm" of the "DRC" package $[13,46,47]$. A three parameter log-logistic model was used:

$$
f(x)=\frac{\operatorname{gmax}}{1+\left(\frac{x}{T 50}\right)^{b}}
$$

The parameters are: (b) slope curvature, (gmax) final germination and (T50) germination speed, intended as time (days/weeks) required to reach half of the final germination or emergence. Parameter comparison on final germination and germination speed were then performed to assess differences among treatment (significance $p<0.05$ ).

To test the hypothesis of treatment and compound effect on germination in the field (in buried bags) and plant survival, an exact binomial test on the probability of success in a Bernoulli trial, between each treatment, was performed (confidence level $=0.95$ ). in the Ime4 package for R [48], using compounds; untreated control (ctrl) vs treated without SA (NO) 

as fixed variables and the replicates (plots) as a random variable.

ANOVA (Type II Wald chi square tests) was employed to detect significant treatment effects. If such significance was detected a pairwise t-test was performed to compare the levels within the treatment. All data analysis was performed in the R statistical environment [49].

Fig 1. Seeds of the three grass species tested. In each image are presented the encrusted (blue) and untreated-imbibed

Fig 2. Climate condition at the field site. (A) the daily average for day (orange) and night (blue) temperature (B) volumetric water content in the soil at $1 \mathrm{~cm}$ depth for the first 10 weeks of the experiment, when germination and emergence were recorded. (C) Weekly maximum (tMax) and minimum (tMin) temperature, and total precipitation (Prec (mm)) for the period between the end of the emergence experiment and the recording of plant survival (July 2017 - March 2018) at a nearby meteorological station.

\section{Results}

In the first two sections are reported the results of seed germination under laboratory conditions and growth data, collected at the field site.

\section{Encrusting and imbibition treatment}

Encrusting treatment (Encr) had higher or similar germination than the control (Ctrl), whilst

imbibition treatment $(\mathrm{Imb})$ at times resulted in lower cormination. Final germination of $\Delta$, scabra treated seed, tested in lab conditions, was not significantly different from the untreated control, and only slightly but significantly $(P<0.001)$ increased in germination speed $(T 50)$ of 0.5 days, for both imbibed and encrusted seed. When tested in field conditions, the encrusted seed had lower final emergence than the control (Ctrl: $52 \pm 1.6 \%$, Encr: $45 \pm 2.4 \%, \mathrm{P}<0.001$ ) while imbibed seeds showed no significant difference (Fig 3). 
Under laboratory conditions encrusted $M$. stipoides seeds $(86 \pm 2.1 \%)$ germination was higher than in the control $(73 \pm 2.2 \%, P<0.001)$, but $8.9 \%$ lower for imbibed seed $(P<0.05)$. Similarly, final emergence in the field was higher for encrusted seed (Encr: $48 \pm 1.0 \%$, Ctrl: $35 \pm 1.0 \%$ ) with imbibition increasing emergence by $4 \%(P<0.05)$.

As with $M$. stipoides, germination of $R$. geniculatum was significantly higher for encrusted seeds (68 $\pm 1.5 \%$ ) with th 10 Nest for imbibed seeds ( $51 \pm 1.4 \%)$, (Ctrl: $58 \pm 1.5 \%)$. However, there was no difference in seeding emergence in response to seed treatment under field conditions.

\section{Salicylic acid effects on germination with low water availability and field}

\section{emergence}

To assess the effect of SA, seeds that were provided SA (via imbibition and encrusting) were compared to seeds that received the treatments without SA (NO). If a significant difference was detected, SA delivery methods of encrusting (ES) and imbibing (IS) were then compared. The high variability in the results suggested that SA has limited effects on promoting germination and emergence.

Final germination at optimal water potentials in $A$. scabra was significantly $(P<0.05)$ reduced by 4.3\% with SA treatment (Error! Reference source not found.). At reduced water availability of -0.6, 0.9, and -1.2 MPa SA treatments generally showed a slight but non-significant improvement in final germination. When tested in the field, SA treatments did not affect germination but reduced final emergence (NO: $51 \pm 1.1 \%, \mathrm{SA}: 44 \pm 1.1 \%, \mathrm{P}<0.001$ ) with SA encrusted seed emerging $5.6 \%$ lower than SA imbibed seeds.

Similarly, M. stipoides germination at optimal conditions was reduced in SA treated seed by $7.9 \%$ $(P<0.05)$. SA delivered through encrusting resulted in better germination $(77 \pm 2.1 \%)$ than $S A$ imbibed seed $(57 \pm 2.2 \%)$. Under limiting water potentials of $-0.6 \mathrm{MPa}$, germination for SA treated seed was improved from $77 \% \pm 1.9 \%$ to $86 \pm 1.9 \%$, and encrusting allowed for a $12.7 \%$ increase in 
germination compared to imbibing. However, at lower water potentials, SA treatment reduced final germination by $5.6 \%(P<0.05)$ at $-0.9 \mathrm{MPa}$ and by $11.2 \%(\mathrm{P}<0.01)$ at $-1.2 \mathrm{MPa}$. In both situations encrusting allowed for better germination then imbibition. Field germination and emergence of $M$. stipoides were not significantly affected by SA treatment, but both treatments had higher emergence than the untreated control.

When final germination was tested on $R$. geniculatum, no significant difference between seed treated with and without SA was detected at optimal conditions and with reduced water availability.

The only effect of SA was a delay in germination at $0.0 \mathrm{MPa}$ of $\mathrm{U} .4$ days. Field germination was no different for seed troated with and without SA, however both treatments had lower germination than the untreated control. Between seeds treated with and without SA, there was no difference in field emergence. However, seed treated without SA had significantly lower germination $(p<0.05)$ than the untreated control. Emergence in SA treated seeds was slightly higher, but not significant. The results of germination and emergence experiment are provided in the supplementary file S1_GerminationEmergenceAnalysisResults.pdf.

\section{1}

\section{Survival and plant growth in field site conditions}

Plant survival was examined in situations where intraspecific competition was maintained high (line experiment) or reduced (plot experiment). In both scenarios, SA improved plant survival and growth. In the "line experiment" the survival of plants that emerged from untreated seed was $32.3 \%$ for $A$. scabra, $41.2 \%$ for $M$. stipoides and $42.6 \%$ for $R$. geniculatum. Plants emerging from SA treated seed, compared to seeds treated without $\mathrm{SA}$, had a significantly $(\mathrm{P}>0.001)$ increased survival by $12.9 \%$ in $A$. scabra, $13.5 \%$ in M. stipoides and $11.8 \%$ in R. geniculatum. In A. scabra, SA delivered through encrusting improve survival by $9.8 \%(P>0.001)$ compared to SA delivered through imbibing. In $M$. survival. 
In the plot experiment, the average survival of seedlings in the untre ${ }^{+n} \gamma$ control was of $82.5 \%$ for $A$. scabra, $82.5 \%$ for $M$. stipoides and $77.5 \%$ for $R$. geniculatum. In SA treated M. stipoides and $R$. geniculatum, compared treated without $S A$, survival was significantly improved $(P<0.01)$, by $8.2 \%$ and $15 \%$ respectively and in $A$. scabra, survival was improved by $6.25 \%$, but the difference was not for M. stipoides and R. geniculatum, SA treatment improve survival by $17.5 \%$ and $10 \%$ respectively, compared to seed treated without SA (Error! Reference source not found.). significant difference was detected between SA and non-SA treatments in eitrer measurement. For M. stipoides, plant height for SA treated seed was significantly improved $(P<0.05)$ from $41 \mathrm{~cm} \pm 1.7$ $\mathrm{cm}$ (untreated control) and $43 \mathrm{~cm} \pm 1.0 \mathrm{~cm}$ (treated seed without SA), to $46 \mathrm{~cm} \pm 1.0 \mathrm{~cm}$. Dry aboveground biomass was also higher in SA treatment $(3.4 \mathrm{~g} \pm 0.22 \mathrm{~g})$ compared to untreated controls $(2.2$ $\mathrm{g} \pm 0.25 \mathrm{~g}$ ) and without $\mathrm{SA}(2.7 \mathrm{~g} \pm 0.25 \mathrm{~g})$ (both $\mathrm{P}<0.05)$. In $R$. geniculatum, there was no significant difference in height. Dry biomass for SA treatment $(1.5 \mathrm{~g} \pm 0.08 \mathrm{~g})$ was significantly higher $(\mathrm{P}>0.05)$ than treated without SA $(1.2 \mathrm{~g} \pm 0.10 \mathrm{~g})$, but not significant compared to the untreated control $(1.3 \mathrm{~g}$ $\pm 0.09 \mathrm{~g})$. No significant difference between SA delivery through imbibing or encrusting, in terms of plant growth, was detected in the study species.

Fig 3. Seed treatment germination and emergence curves. Cumulative germination/emergence percentage curves of the three different seed treatment tested: untreated (ctrl), encrusted (Encr), and imbibed (Imb) across the three species tested. The lines represent the cumulative germination curve over time. Data points are the germination recorded on a specific day/week and the shaded areas represent the $95 \%$ confidence intervals. A, B and C germination experiments were in controlled laboratory condition. D, E and F seedling emergence in the field trial.

Fig 4. Salicylic Acid final germination and emergence Final germination and emergence of untreated seeds (Ctrl), seed treated without salicylic acid (No) and seed treated with salicylic acid (SA). A, B and C shows the laboratory germination experiment in petri dishes at $20^{\circ} \mathrm{C}$ at different water potentials ( $X$ axis). D, E shows the germination and emergence results in the field experiment, 3 and 10 weeks after sowing respectively. The species are listed in the $\mathrm{X}$ axis (Aus = Austrostipa scabra, Mic $=$ Microlaena stipoides, Ryt $=$ Rytidosperma geniculatum). Results followed by the same letter for the Water potential (lab experiment) and species (Field experiment) are not statistically different at $p<0.05$ 
Fig 5. Survival and plant growth. Survival and plant growth comparison 40 weeks after sowing, between untreated seeds (Ctrl), seed treated without salicylic acid (No) and seed treated with salicylic acid (SA). (A) plant survival proportion in the plot experiment, where interspecific competition was limited, by removing excess seedlings and leaving 10 seedling per $0.25 \mathrm{~m}^{2}$ plot. (C) Seeds sown on a $1 \mathrm{~m}$ line, without thinning. (C) Average height and (D) biomass of plant collected from the plot experiment. Results followed by the same letter are not statistically different at $p<0.05$.

\section{Discussion}

\section{Seed treatment effects on germination and emergence}

Of the three species tested, only A. scabra showed no treatment (encrusting and imbibition) effect on germination and emergence as predicted. M. stipoides and R. geniculatum showed unexpected, significant differences between treated seeds (imbibed and encrusted) and the control. In the germination experiment, the two species behaved similarly, with encrusted seeds performing better than controls, while imbibition had negative effects on both final germination and germination speed. In this study, seeds were imbibed for 24 hours, following previously described methodology for SA delivery to seeds $[33,50]$. A potential explanation for the reduction in germination of imbibed seed could be anoxic stress due to extended submersion in water and in a water-saturated environment (petri dish). This problem has been reported in seed priming treatments that rely on seed imbibition to trigger pre-germinative metabolic mechanisms [51,52]. Oxygen availability could also explain why encrusted seed performed better than imbibed and untreated seed. During the encrusting process, seed contact with water was limited compared to imbibing. Moreover, the layer of encrusting material could also have acted as a buffer, reducing the water potential at the seed level and allowing for improved gas exchange. Furthermore, the emergence of imbibed seed was unaffected in the moist, but not water-saturated soil conditions. In seed priming treatments, water potential or water oxygenation are usually regulated [53] to avoid anoxic damage. The germination reduction detected in this study for imbibed seed could, therefore, be mitigated by decreasing imbibition time, reducing the water potential, or providing oxygenation to the solution. 


\section{Salicylic acid effect on seed germination and emergence}

Contrary to what was initially hypothesised, SA application did not clearly improve seed germination and emergence in the field and in controlled laboratory condition across a water availability gradient on the tested species, with the exception of $M$. stipoides at -0.6 MPa. M. stipoides seed treated with SA had significantly lower germination at $0.0,-0.9$ and $-1.2 \mathrm{MPa}$, suggesting that this species might be susceptible to the SA concentration tested. Germination response to exogenous SA application is concentration dependent, with inhibition detected at higher concentrations [35]. Reducing SA concentration for M. stipoides, could therefore potentially remove the germination impediments. When a difference in germination was detected for seed treated with SA, encrusted seed performed slightly better than imbibed seeds. However, this difference is most likely due to the process itself, as highlighted previously, other than the efficacy in delivering SA.

A significant drop in emergence by SA treated seed in A. scabra might suggest that the interaction of SA treatment with unidentified variables present in the soil at field site might have triggered a negative response, similar to what was observed in the controlled lab environment. Moreover, the detrimental effect of encrusting could have been determined by the combined effect of SA and the physical constraint of the coatings layer and soil to the emerging seedling. However, this effect was not detected in the other species.

\section{Survival and growth}

In experimental plots where competition was reduced, plants from seed treated with SA resulted in increased height and biomass production in two out of the three species $t \epsilon=\mathrm{SA}$ also provided a significant improvement in plant survival in both scenarios with and without interspecific competition. Although response among species varied, with the least effects detected in A. scabra, the overall trend showed marked benefits in term of survival and plant grown from SA-treated seeds. The improved survival at this stage could be explained by the already described stress resistance proprieties of SA [44]. A potentially significant, yet unintended, result of this experiment is 
the great difference in plant survival between the low and high seedling density (line and plot experiment). According to the seedling emergence data, the seedling density in the line experiment was of 520 seedling $/ \mathrm{m}^{2}$ in $A$. scabra, 430 seedling $/ \mathrm{m}^{2}$ in M. stipoides and 280 seedling $/ \mathrm{m}^{2}$ in $R$. geniculatum, whilst for the plot experiment seedling density was 40 seedling $/ \mathrm{m}^{2}$ across all species. Based on personal observations, the plants with limited competition were generally more developed before summer than the ones in the lines. This would have allowed for the development of a broader and deeper root system with better access to water during the dry summer months ultimately resulting in higher chances of survival. These results suggest that intraspecific competition within these species could play a major role in seedling establishment rate. This factor needs to be taken in consideration when planning for seeding operation, to avoid overseeding and wastage of valuable and expensive seeds [54].

\section{Demographic processes}

In field experiments, soil conditions at the time of germination and emergence (Error! Reference source not found.) were suitable for the germination of these temperate grass species. Differently to what was described by James et al. (2011), where the major bottleneck in seedling recruitment was detected at the emergence phase (when germinated seeds failed to push through the soil), in this experiment, the drop between germination and emergence was relatively small with probability of emergence from germinated seed ranging from 0.92 in A. scabra to 0.61 in $R$. geniculatum (Fig 6). This trend might be due to the favourable climatic ana soil conditions during the year the study was conducted, with average night and daily temperature ranging between $10^{\circ} \mathrm{C}$ and $18^{\circ} \mathrm{C}$, and maintained soil moisture content of $0.08-0.18 \mathrm{~m}^{3} / \mathrm{m}^{3}$ (water potential range between -0.2 and -0.7 $\mathrm{MPa}$ ) during the first month after sowing, when most of the emergence occurred. These conditions have not allowed for the detection of the stress reduction proprieties of SA that were originally hypothesised at the germination and emergence phase. However, the field data, combined with the controlled germination experiment with reduced water availability, suggest that SA might not affect 
seed performances at the establishment phase, as suggested by [34]. Further studies are needed to test this hypothesis under more severe stress conditions and on different species.

Significant effects of SA delivering stress resistance were instead detected on the survival of established plants over the summer when seedlings had to endure prolonged periods with little access to water. Total precipitation between November 2017 and February 2018, removing two major rainy events that happened over a short period $\left(60 \mathrm{~mm}\right.$ on December $20^{\text {th }}$ and $147 \mathrm{~mm}$ on January $18^{\text {th }}$ ) were less than $30 \mathrm{~mm}$ (Fig 2). The effects of the summer drought were evident on the experiment where seedlings were not removed, with the probability of plant survival from an emerged seedling being 0.32 for $A$. scabra, 0.41 for $M$. stipoides and 0.42 for $R$. geniculatum. In this case, SA treated seed survived significantly better than the seed treated without SA for the three species. When considering the cumulative survival from the number of seeds initially sown, SA treatment provides a significantly higher number of successful plant establishment events, even for A. scabra, when emergence of SA treated seed was lower than the seed treated without SA.

\section{SA effect on survival}

In both line and plot experiments, SA treated seeds improved survival, supporting previous evidence that SA exogenous application may deliver drought stress resistance [43]. This improvement in survival might be due to a variety of factors, such as the effect of SA in mediating reactive oxygen species (ROS) and triggering defence-related processes [55], and its effect on productivity and growth [56]. In this study, just one of the three species tested (M. stipoides) showed a higher biomass production as a response to SA treatment. A previously published study reported that externally applied SA had increased root development [57], but root growth was not evaluated in this study. Nevertheless, as this study shows, the effects of exogenous SA delivery are still present months after its application. SA absorbed through the seed (imbibing), or through emerging radicle and roots (encrusting) could be converted in SA glucoside and transferred in the vacuole for storage 
421 [58]. SA glucoside could be mobilized and moved through the plant after been converted in methyl

422 salicylate, and eventually turned back to SA when needed [27].

\section{Encrusting and imbibition}

424 When SA delivery mechanisms of imbibing and encrusting were compared in terms of improving

425 plant survival, a significant difference was rarely detected, suggesting that seed encrusting could be used to deliver SA and its stress resistance inducing proprieties. The advantage of using SA in the seed coating processes over imbibition lies in the capability of storing seed after treatment. Seed imbibition can trigger a seed priming effect that could improve germination speed and synchronicity in the short term [59], but, such imbibition could accelerate seed ageing processes, reducing seed shelf-life and storability [60]. Another advantage of seed coating over imbibition is that while it delivers SA stress resistance, it can also improve seed handling and sowability, along with a wide variety of active ingredients, such as protectants, micronutrients, germination promoters and microorganism [24]. Most of these coating treatments still need to be tested on native species for restoration, but their combined impact on seed germination, emergence, growth and plant establishment could improve the successful deployment of native seed onto degraded landscapes, ultimately allowing for a more cost-effective seed-based restoration.

Fig 6. Cumulative survival proportion. Demographic process through various life stages for the three species tested without treatment, treated without SA and treated with SA. On the top of each graph, in red, are reported the probability of transitioning between life stages. This demographic data are based on the "in line' experiment whereas seedling were not removed after emergence and intraspecific competition affected plant survival.

\section{Acknowledgements}

443 We acknowledge that the research undertaken and presented here was done on Wadjuk Noongar country and pay our respects to their elders, past, present and emerging. 
This study is dedicated to the memory of the late Dr Tissa Senaratna who was instrumental in establishing salicylic acid as a key principle for improving plant growth and development and without whom this and many other studies would not have been possible.

S.P. was the recipient of a Curtin University International Postgraduate Research Scholarship. A.T.C is the recipient of the Research Fellowship in Restoration Ecology jointly funded by the EcoHealth Network, Gelganyem Limited, and Curtin University. Seed were donated by Native Seed Pty Ltd. This

\section{References}

1. Nellemann C, Corcoran E. Dead Planet, Living Planet. Biodiversity and ecosystem restoration

2. Costanza R, Arge R, de Groot R, Farberk S, Grasso M, Hannon B, et al. The value of the world 's ecosystem services and natural capital. Nature. 1997;387: 253-260. doi:10.1038/387253a0

3. Palmer MA, Filoso S. Restoration of Ecosystem Services for Environmental Markets. Science (80- ). 2009;325: 575-576. doi:10.1126/science.1172976 for sustainable development. Nellemann C, Corcoran E, editors. Challenges. Norway: United editor. Rome: Food and Agriculture Organization of the United Nations; 2005. Available: http://www.fao.org/docrep/008/y8344e/y8344e00.htm

7. O'Mara FP. The role of grasslands in food security and climate change. Ann Bot. 2012;110: 
1263-1270. doi:10.1093/aob/mcs209

8. Gang C, Zhou W, Chen Y, Wang Z, Sun Z, Li J, et al. Quantitative assessment of the contributions of climate change and human activities on global grassland degradation. Environ Earth Sci. 2014;72: 4273-4282. doi:10.1007/s12665-014-3322-6

9. Gibson DJ. Grasses and Grassland Ecology. New York: Oxford University Press; 2009.

10. Conrad MK, Tischew S. Grassland restoration in practice: Do we achieve the targets? A case study from Saxony-Anhalt/Germany. Ecol Eng. 2011;37: 1149-1157. doi:10.1016/j.ecoleng.2011.02.010

11. Pedrini S, Dixon KW. International principles and standards for native seeds in ecological restoration. Restor Ecol. 2020;28: 286-303. doi:10.1111/rec.13155

12. Cross AT, Stevens JC, Dixon KW. One giant leap for mankind: can ecopoiesis avert mine tailings disasters? Plant Soil. 2017;421: 1-5. doi:10.1007/s11104-017-3410-y

14. Orrock JL, Witter MS, Reichman OJ. APPARENT COMPETITION WITH AN EXOTIC PLANT REDUCES NATIVE PLANT ESTABLISHMENT. Ecology. 2008;89: 1168-1174. doi:10.1890/07-

13. Lewandrowski W, Erickson TE, Dixon KW, Stevens JC. Increasing the germination envelope under water stress improves seedling emergence in two dominant grass species across different pulse rainfall events. Firn J, editor. J Appl Ecol. 2017;54: 997-1007. doi:10.1111/1365-2664.12816 0223.1

15. James JJ, Svejcar TJ, Rinella MJ. Demographic processes limiting seedling recruitment in arid grassland restoration. J Appl Ecol. 2011;48: 961-969. doi:10.1111/j.1365-2664.2011.02009.x

16. Pyke DA. Comparative demography of co-occurring introduced and native tussock grasses: persistence and potential expansion. Oecologia. 1990;82: 537-543. doi:10.1007/BF00319798

17. Merritt DJ, Dixon KW. Restoration Seed Banks--A Matter of Scale. Science (80- ). 2011;332: 424-425. doi:10.1126/science.1203083

18. Menz MHM, Dixon KW, Hobbs RJ. Hurdles and Opportunities for Landscape-Scale Restoration. Science (80- ). 2013;339: 526-527. doi:10.1126/science.1228334

19. Pedrini S, Merritt DJ, Stevens J, Dixon K. Seed Coating: Science or Marketing Spin? Trends Plant Sci. 2017;22: 106-116. doi:10.1016/j.tplants.2016.11.002

20. Taylor AG, Allen PS, Bennett M a., Bradford KJ, Burris JS, Misra MK. Seed enhancements. Seed Sci Res. 1998;8: 245-256. doi:10.1017/S0960258500004141

21. Madsen MD, Kostka SJ, Hulet A, Mackey BE, Matthew A. Surfactant Seed Coating - a Strategy To Improve Turfgrass Establishment on Water Repellent Soils. In: Castelani P, editor. Proceedings of the 10th International Symposium on Adjuvants for Agrochemicals, ISAA 2013, 

22-26 April, Foz Do Iguaçu, Brazil, Organized Under the Auspices of ISAA Society. ISAA Society; 2013. pp. 205-210.

22. Madsen MD, Davies KW, Williams CJ, Svejcar TJ. Agglomerating seeds to enhance native seedling emergence and growth. J Appl Ecol. 2012;49: 431-438. doi:10.1111/j.13652664.2012.02118.x

23. Pearson DE, Valliant M, Carlson C, Thelen GC, Ortega YK, Orrock JL, et al. Spicing up restoration: can chili peppers improve restoration seeding by reducing seed predation? Restor Ecol. 2019;27: 254-260. doi:10.1111/rec.12862

24. Pedrini S, Balestrazzi A, Madsen MD, Bhalsing K, Hardegree SP, Dixon KW, et al. Seed enhancement: getting seeds restoration-ready. Restor Ecol. 2020;28: rec.13184. doi:10.1111/rec.13184

25. Raskin I, Skubatz H, Tang W, Meeuse BJD. Salycilic acid levels in thermogenic and non termogenic plants. Ann Bot. 1990;66: 369-373.

26. Rivas-San Vicente M, Plasencia J. Salicylic acid beyond defence: Its role in plant growth and development. Journal of Experimental Botany. 2011. pp. 3321-3338. doi:10.1093/jxb/err031

27. Park S, Kaimoyo E, Kumar D, Mosher S, Klessig DF. Methyl salicylate is a critical mobile signal for plant systemic acquired resistance. Science. 2007;318: 113-116. doi:10.1126/science.1147113

28. Dat JF, Capelli N, Van Breusegem F. The Interplay Between Salicylic Acid and Reactive Oxygen Species During Cell Death in Plants. Salicylic Acid: A Plant Hormone. 2007. pp. 247-276. doi:10.1007/1-4020-5184-0_9

29. Horvat E, Gabriella S, Janda T. Induction of Abiotic Stress Tolerance by Salicylic Acid Signaling. J Plant Growth Regul. 2007;26: 290-300. doi:10.1007/s00344-007-9017-4

30. Senaratna T, Touchell D, Bunn E, Dixon K. Acetyl salicylic acid (Aspirin) and salicylic acid induce multiple stress tolerance in bean and tomato plants. Plant Growth Regul. 2000;30: 157-161. doi:10.1023/A:1006386800974

31. Stevens J, Senaratna T, Sivasithamparam K. Salicylic acid induces salinity tolerance in tomato (Lycopersicon esculentum cv. Roma): Associated changes in gas exchange, water relations and membrane stabilisation. Plant Growth Regul. 2006;49: 77-83. doi:10.1007/s10725-0060019-1

32. Lee S, Park C-M. Modulation of reactive oxygen species by salicylic acid in Arabidopsis seed germination under high salinity. Plant Signal Behav. 2010;5: 1534-1536. doi:10.4161/psb.5.12.13159

33. Sharafizad M, Naderi A, Ata siadat S, Sakinejad T, Lak S. Effect of Salicylic Acid Pretreatment 
on Germination of Wheat under Drought Stress. J Agric Sci. 2013;5: 179-199. doi:10.5539/jas.v5n3p179

34. Xie Z, Zhang ZL, Hanzlik S, Cook E, Shen QJ. Salicylic acid inhibits gibberellin-induced alphaamylase expression and seed germination via a pathway involving an abscisic-acid-inducible WRKY gene. Plant Mol Biol. 2007;64: 293-303. doi:10.1007/s11103-007-9152-0

35. Guan L, Scandalios JG. Developmentally related responses of maize catalase genes to salicylic acid. Proc Natl Acad Sci U S A. 1995;92: 5930-5934. doi:10.1073/pnas.92.13.5930

36. Guan Y, Cui H, Ma W, Zheng Y, Tian Y, Hu J. An Enhanced Drought-Tolerant Method Using SALoaded PAMPS Polymer Materials Applied on Tobacco Pelleted Seeds. Sci World J. 2014;2014: 9. doi:10.1155/2014/752658

37. Guan Y, Li Z, He F, Huang Y, Song W, Hu J. "On-Off” Thermoresponsive Coating Agent

38. Waters C, Whalley W, Huxtable C. Grassed up. 2001; 1-50.

39. De Vitis M, Hay FR, Dickie JB, Trivedi C, Choi J, Fiegener R. Seed storage: maintaining seed

42. Pedrini S, Bhalsing K, Cross AT, Dixon KW. Protocol Development Tool (PDT) for seed viability and vigor for restoration use. Restor Ecol. 2020;28: 249-255. doi:10.1111/rec.13174

40. Taylor AG, Prusinski J, Hill HJ, Dickson MD. Influence of Seed Hydration on Seedling Performance. Horttechnology. 1992;2: 336-344. doi:10.21273/HORTTECH.2.3.336

41. Stevens J, Chivers I, Symons D, Dixon K. Acid-digestion improves native grass seed handling and germination. Seed Sci Technol. 2015;43: 313-317. doi:10.15258/sst.2015.43.2.19

44. Khan MIR, Fatma M, Per TS, Anjum NA, Khan NA. Salicylic acid-induced abiotic stress

46. Ritz C, Baty F, Streibig JC, Gerhard D. Dose-response analysis using R. PLoS One. 2015;10: 1-

47. Ritz C, Streibig JC, Ritz, C. \& Streibig JC. Bioassay Analysis using R. J Stat Softw. 2005;12: 1-22. doi:10.18637/jss.v012.i05

48. Bates D, Mächler M, Bolker B, Walker S. Fitting Linear Mixed-Effects Models Using Ime4. J 
Stat Softw. 2015;67. doi:10.18637/jss.v067.i01

49. R Core Team. R: A Language and Environment for Statistical Computing.itle. 2015.

50. Senaratna T, Merritt D, Dixon K, Bunn E, Touchell D, Sivasithamparam K. Benzoic acid may act as the functional group in salicylic acid and derivatives in the induction of multiple stress tolerance in plants. Plant Growth Regul. 2003;39: 77-81. doi:10.1023/A:1021865029762

51. Chojnowski M, Corbineau F, Côme D. Physiological and biochemical changes induced in sunflower seeds by osmopriming and subsequent drying, storage and aging. Seed Sci Res. 1997;7. doi:10.1017/S096025850000372X

52. Kildisheva OA, Dixon KW, Silveira FAO, Chapman T, Di Sacco A, Mondoni A, et al. Dormancy and germination: making every seed count in restoration. Restor Ecol. 2020; rec.13140. doi:10.1111/rec.13140

53. Bujalski W, Nienow AW. Large-scale osmotic priming of onion seeds: a comparison of different strategies for oxygenation. Sci Hortic (Amsterdam). 1991;46: 13-24. doi:10.1016/0304-4238(91)90088-G

54. Shaw N, Barak RS, Campbell RE, Kirmer A, Pedrini S, Dixon K, et al. Seed use in the field: delivering seeds for restoration success. Restor Ecol. 2020;28: rec.13210. doi:10.1111/rec.13210

55. Garretón V, Holuigue L, Salinas P, Blanco F, GarretÃ "n V. Salicylic Acid and Reactive Oxygen Species in the Activation of Stress Defense Genes. Salicylic Acid: A Plant Hormone. 2007. pp. 197-246. doi:10.1007/1-4020-5184-0_8

56. Larqué-Saavedra A, Martin-Mex R. Effects of Salicylic Acid on the Bioproductivity of Plants. Salicylic Acid: A Plant Hormone. 2007. pp. 15-23. doi:10.1007/1-4020-5184-0_2

57. Gutiérrez-Coronado MA, Trejo-López C, Larqué-Saavedra A. Effects of salicylic acid on the growth of roots and shoots in soybean. Plant Physiol Biochem. 1998;36: 563-565. doi:10.1016/S0981-9428(98)80003-X

58. Maruri-López I, Aviles-Baltazar NY, Buchala A, Serrano M. Intra and extracellular journey of the phytohormone salicylic acid. Front Plant Sci. 2019;10: 1-11. doi:10.3389/fpls.2019.00423

59. Paparella S, Araújo SS, Rossi G, Wijayasinghe M, Carbonera D, Balestrazzi A. Seed priming: state of the art and new perspectives. Plant Cell Rep. 2015;34: 1281-1293. doi:10.1007/s00299-015-1784-y

60. Hussain S, Zheng M, Khan F, Khaliq A, Fahad S, Peng S, et al. Benefits of rice seed priming are offset permanently by prolonged storage and the storage conditions. Sci Rep. 2015;5: 8101. doi:10.1038/srep08101 


\section{Supporting information}

611 S1_GerminationEmergenceAnalysisResults.pdf. Final germination and T50 value of germination

612 experiments of the three test species at full and reduced water potential and emergence in the field

613 experiment. Statistics obtained with parameter comparison of DRM model comparing treatment, SA,

614 and combination of treatment and SA against the untreated control. 

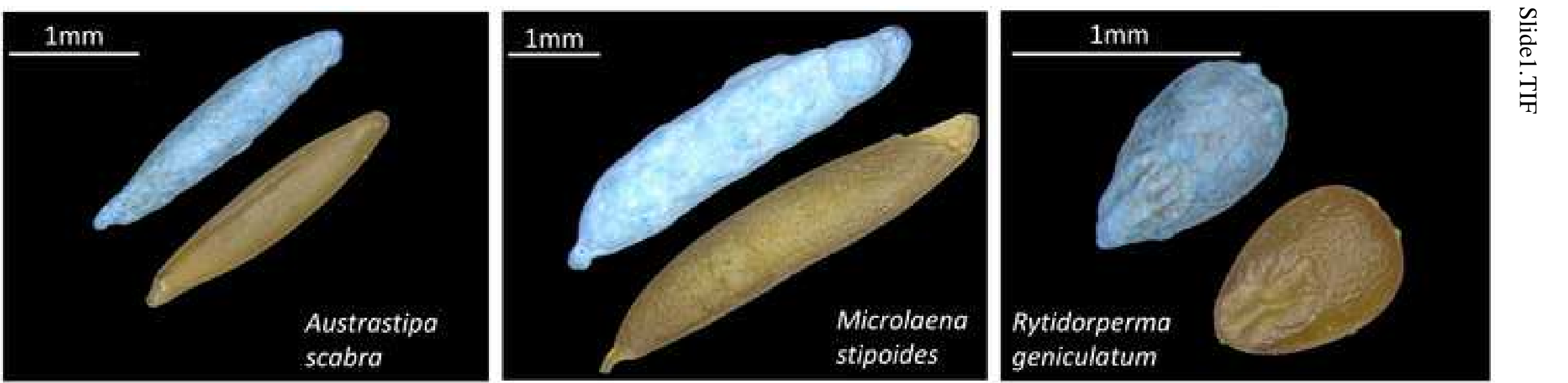

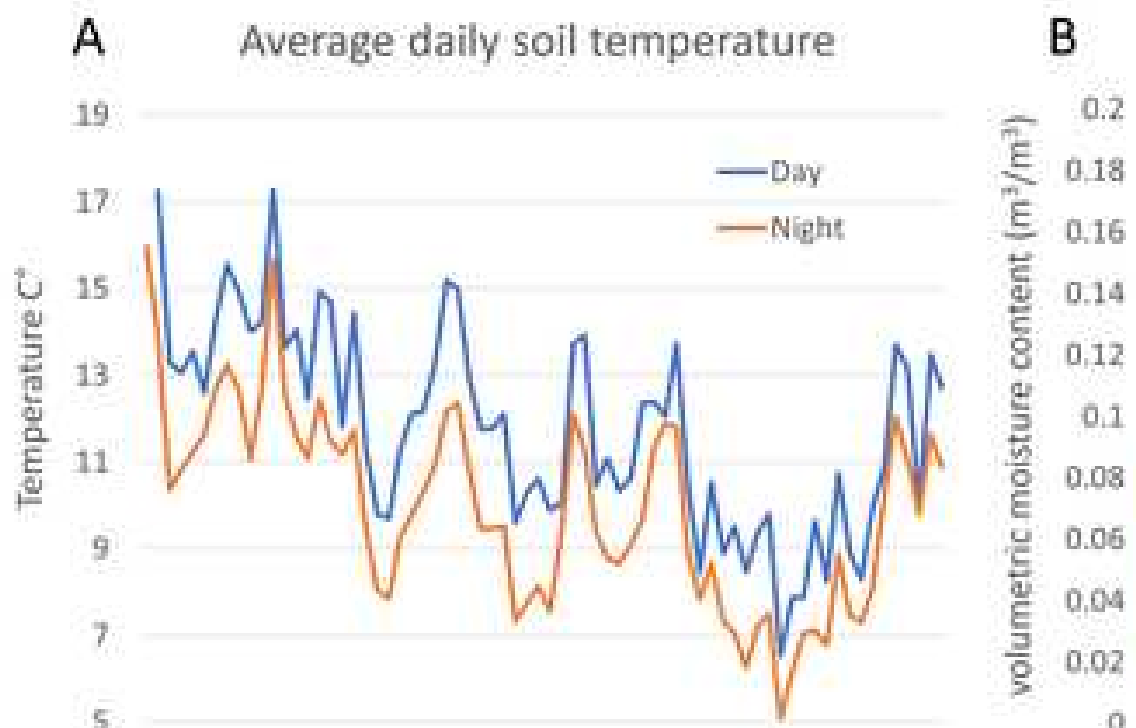

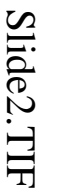

5

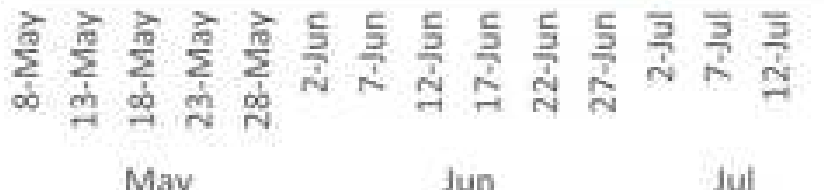

Average daily soil water content

C

Weekley temperature and prec $\overline{\bar{n}}$ tation at Dwellingup

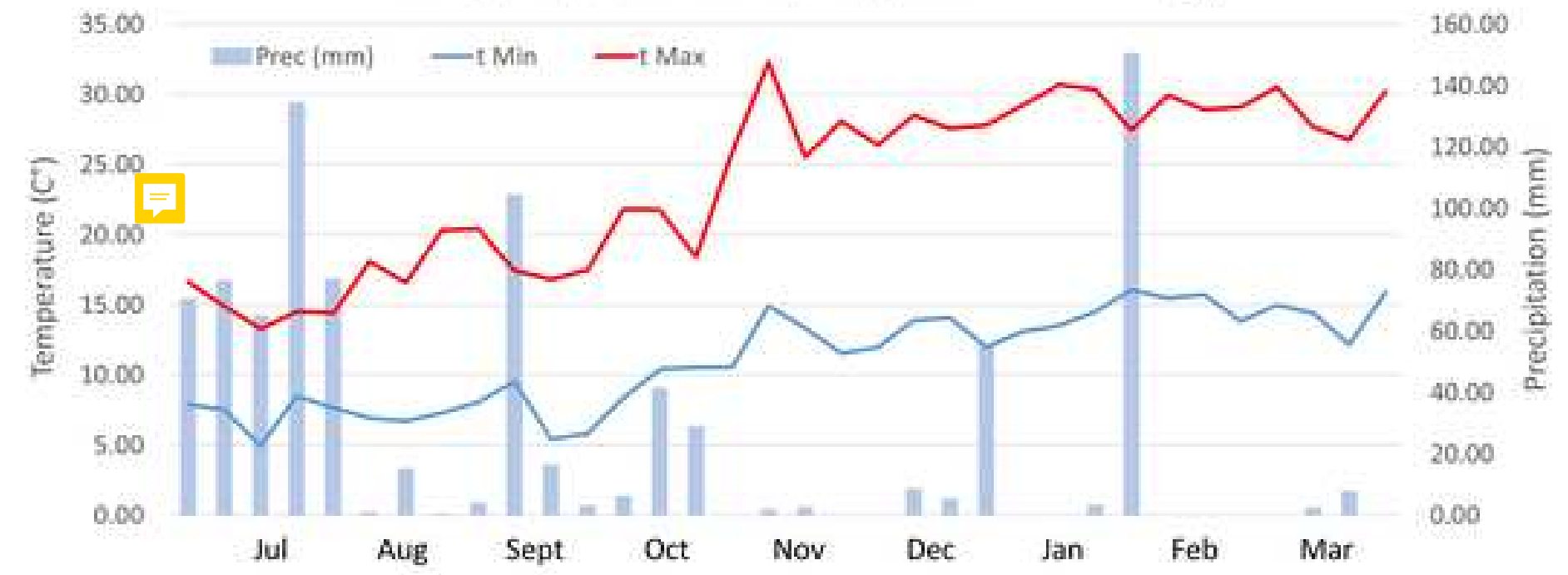


Slide3.TIF

\section{LAB GERMINATION}

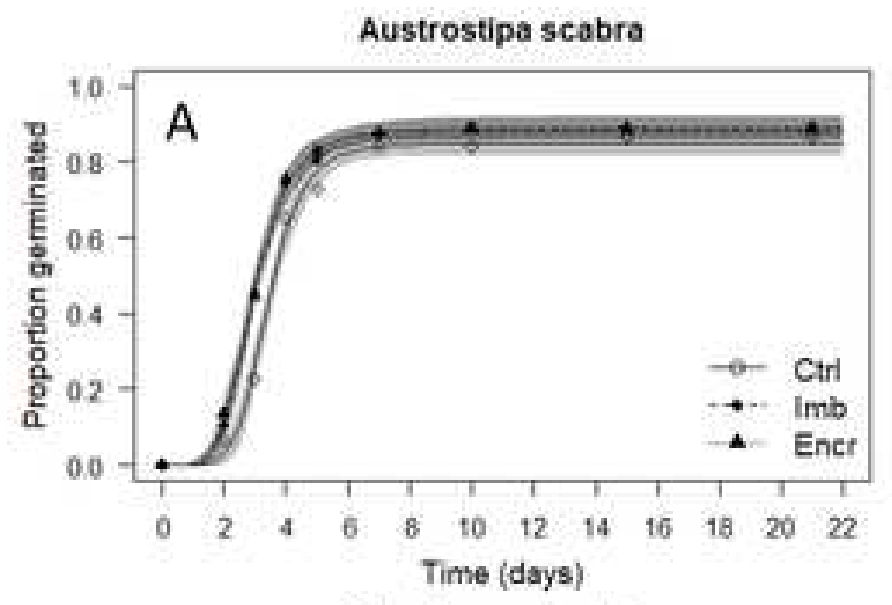

Microlaena stipoides

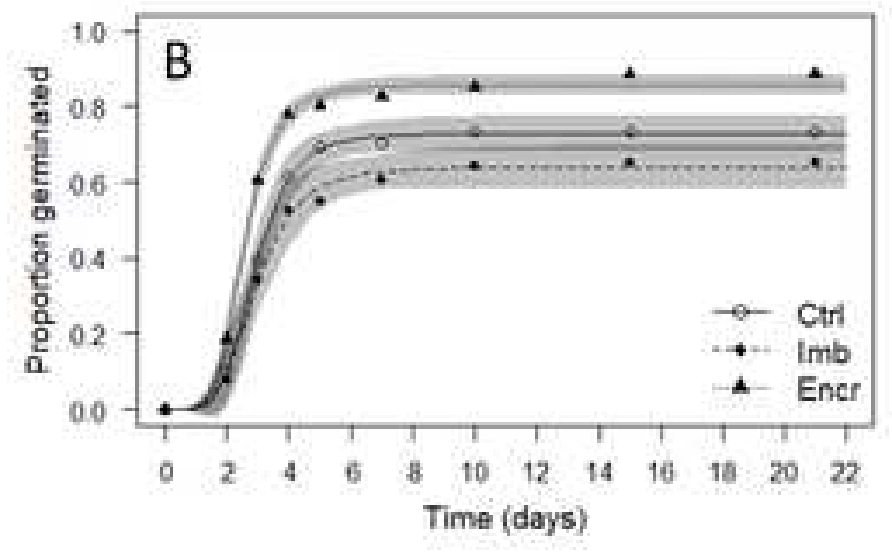

Rytidosperma geniculatum

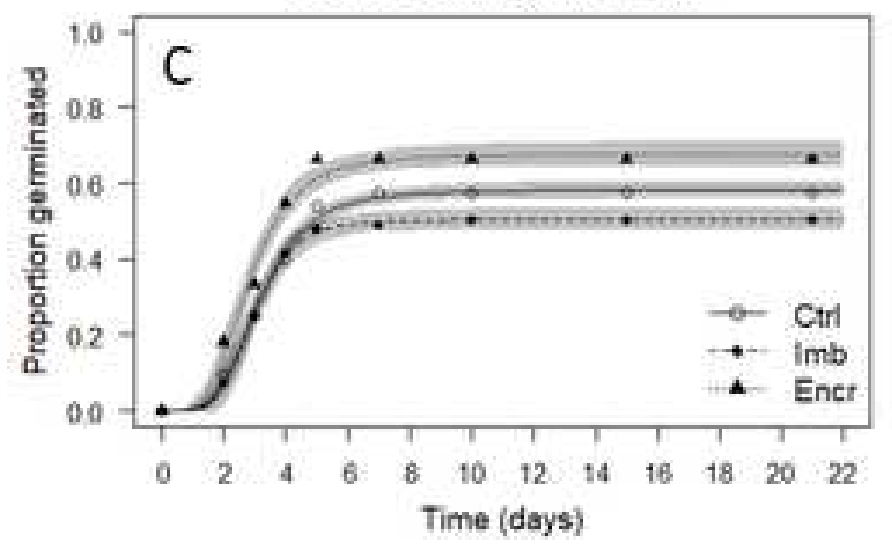

FILED EMERGENCE

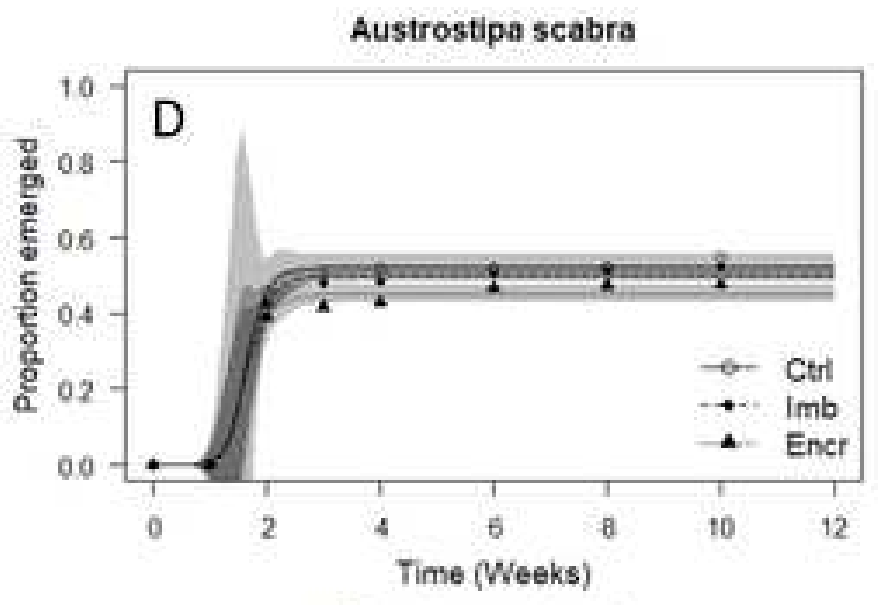

Microlaena stipoides

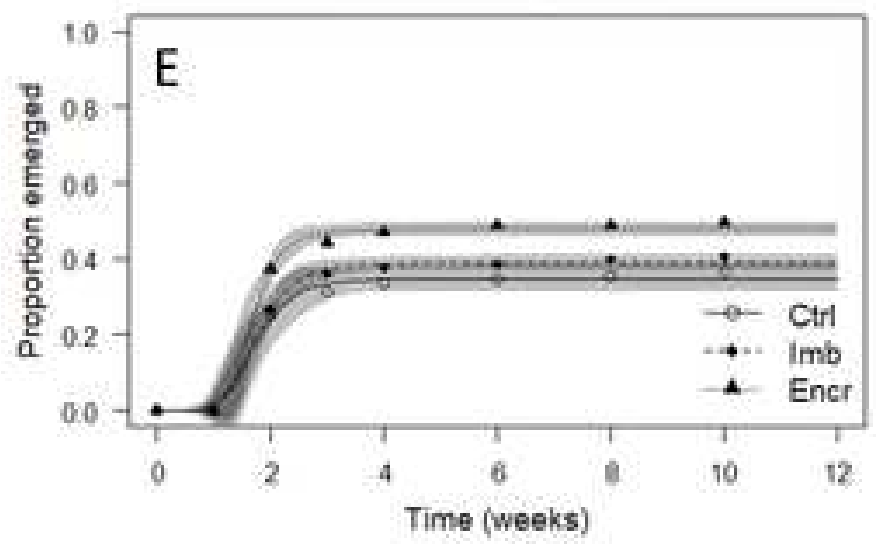

Rytidosperma geniculatum

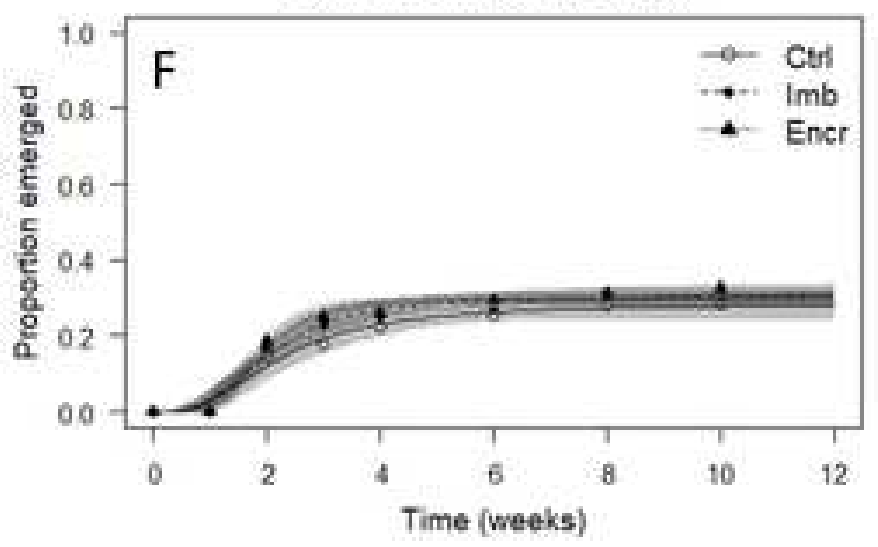


Slide4.TIF

\section{Lab experiment}

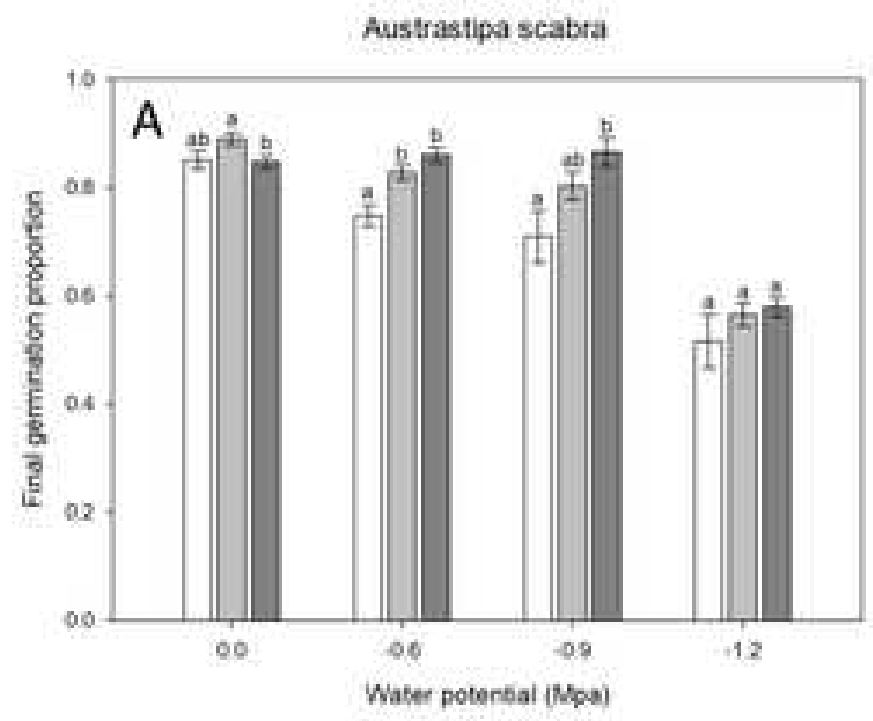

Microlaena stipoides

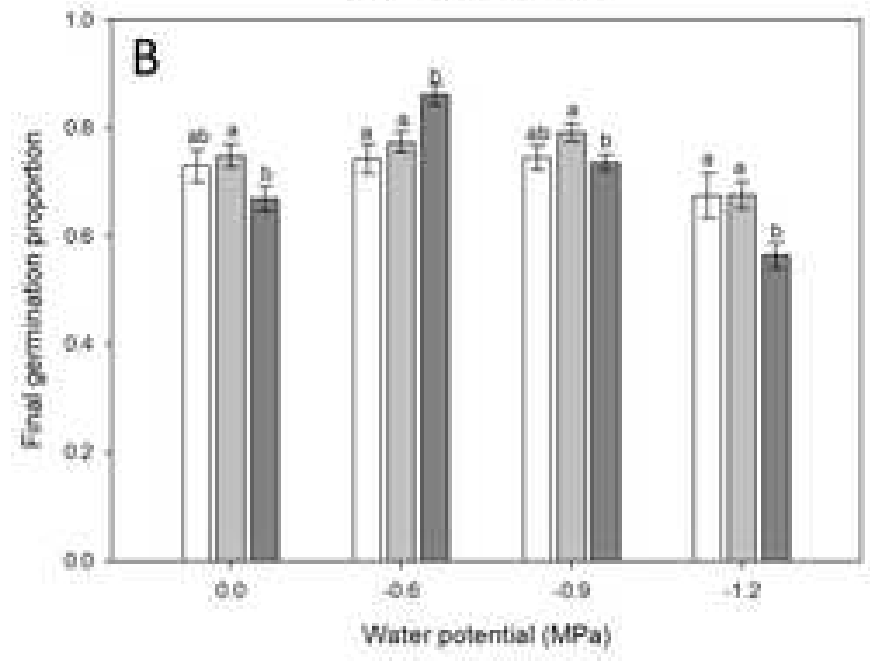

Rytidosperma geniculatum

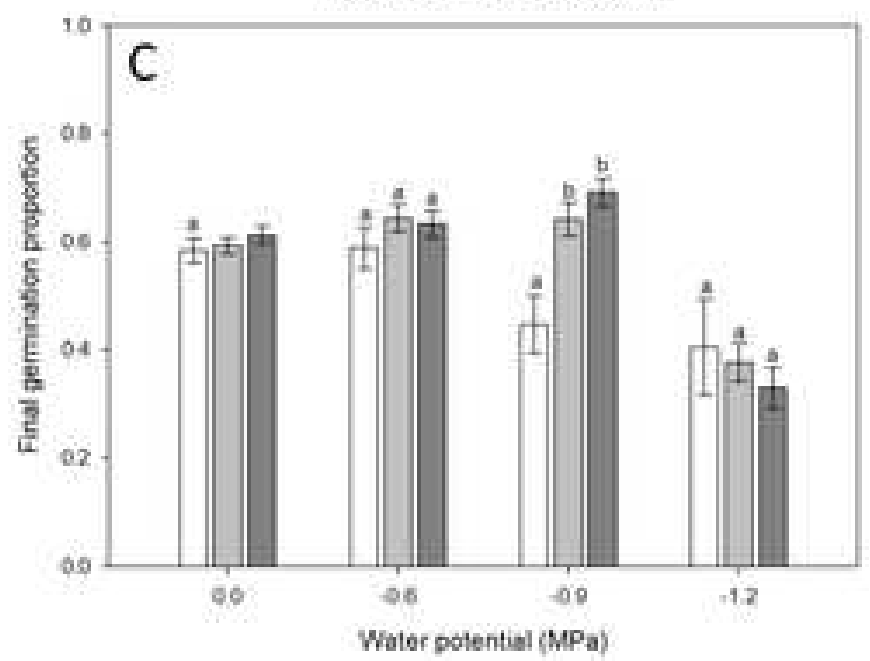

Field experiment

Germination in the field ( 3 weeks)

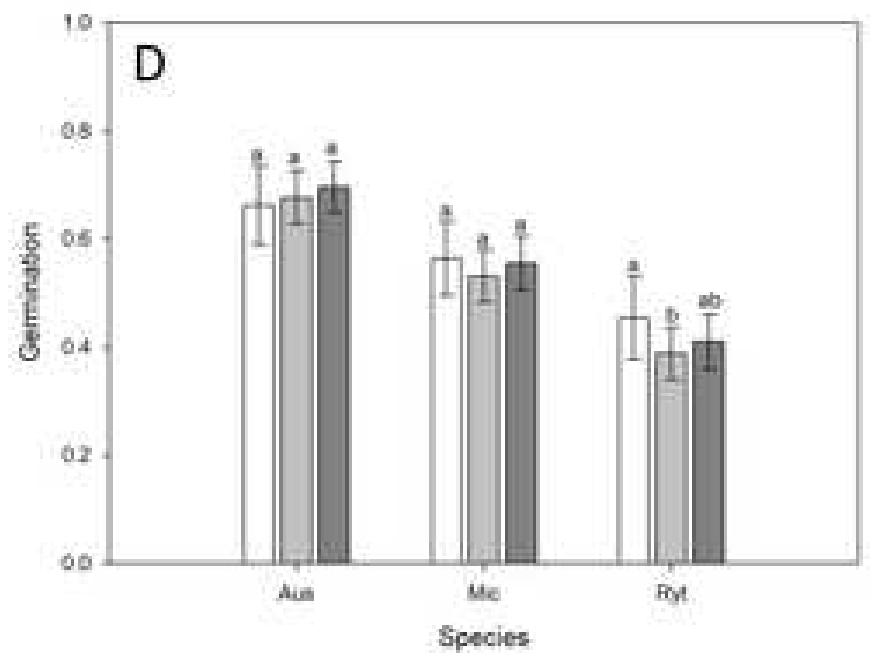

Emergence in the field (10 weeks)

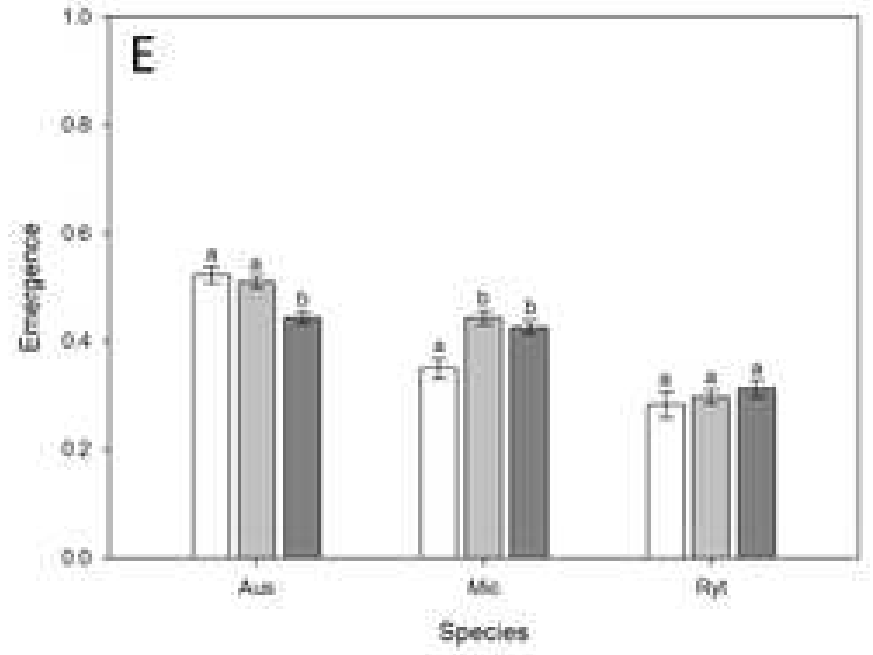

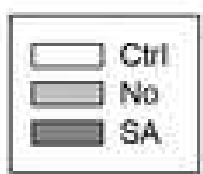



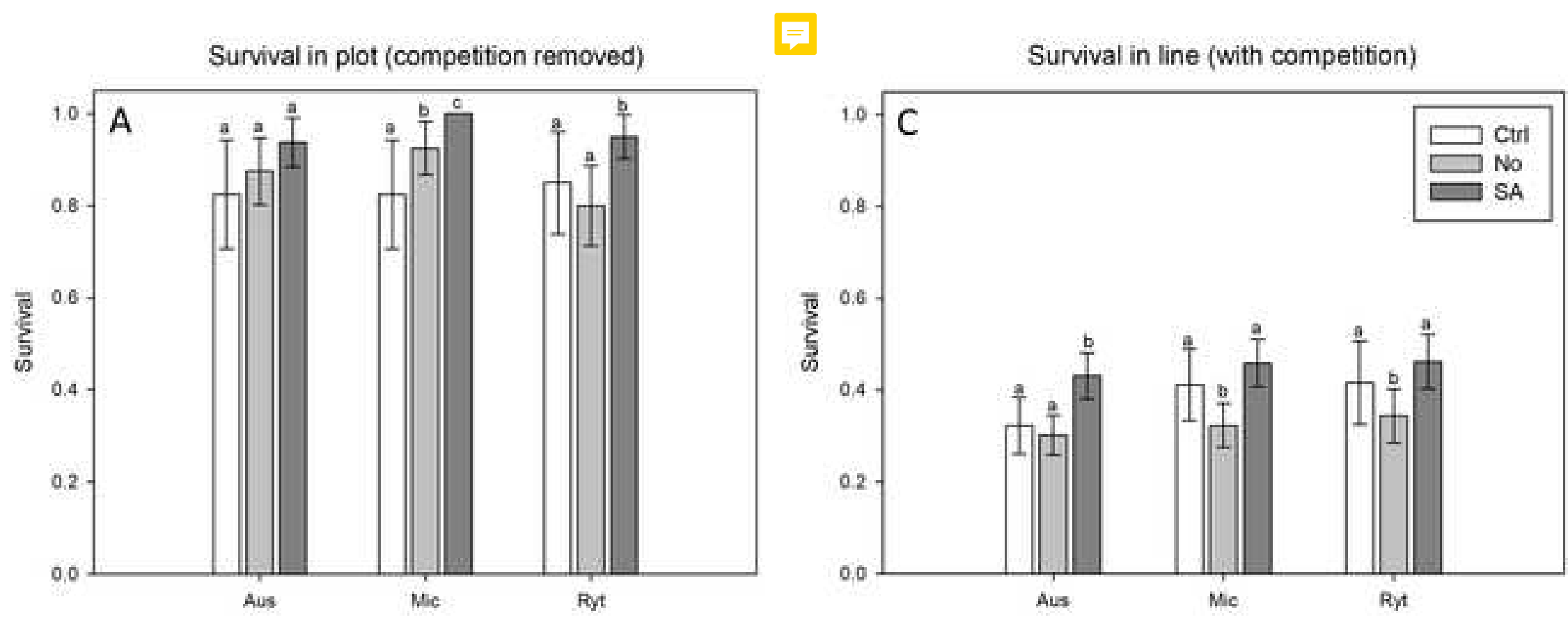

Height

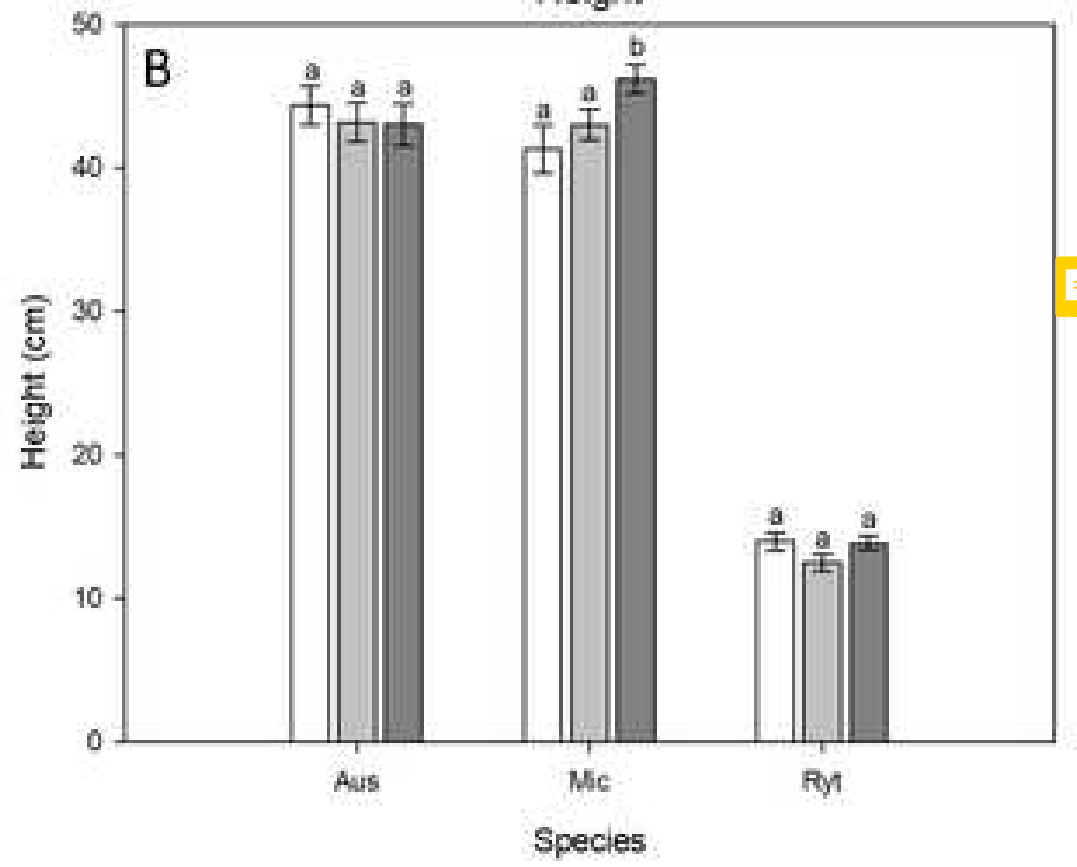

Survival in line (with competition)

吕

Dry biomass

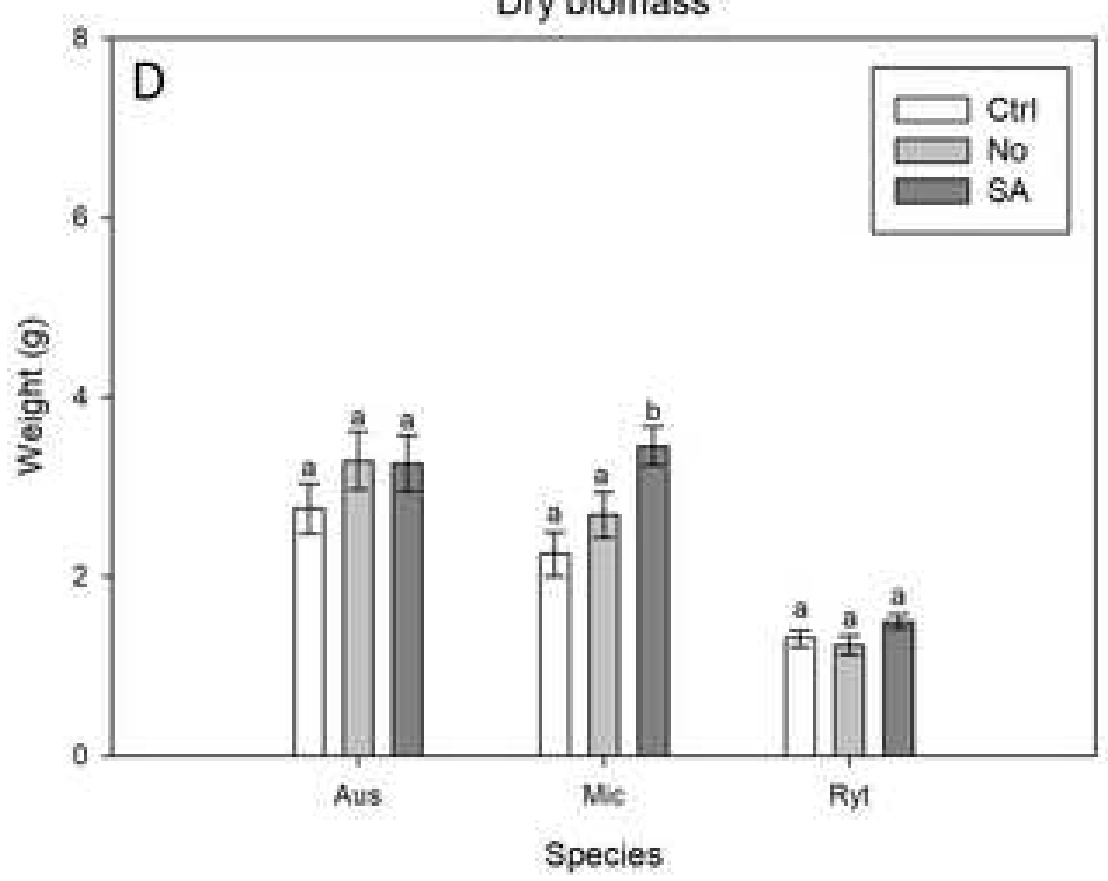


Click here to access/download Supporting Information

S1_GerminationEmergenceAnalysisResults.pdf 